\title{
Fokusgruppeintervju fungerer utmerket som videokonferanse
}

Fokusgruppeintervjuer kan gjennomføres som videokonferanse uten at kvaliteten på forskningen blir dårligere enn om man møtes fysisk.

\section{Karen Rosnes Gissum}

Kreftsykepleier

Norske Kvinners Sanitetsforening

\section{Sigrunn Drageset}

Førsteamanuensis og anestesisykepleier

Institutt for helse- og omsorgsvitskap, Høgskulen på Vestlandet

Fokusgruppeintervju

Videokonferanse

\section{Hovedbudskap}

Hensikten med denne artikkelen er å belyse våre erfaringer med å gjennomføre fokusgruppeintervju ved å bruke videokonferanse. Informantene i vårt forskningsprosjekt var kvinner som var kirurgisk behandlet for eggstokkreft, fra ulike deler av landet. For å kunne gjennomføre fokusgruppeintervjuene og få kvinnenes erfaringer og deres brukerperspektiv, benyttet vi videokonferanse. Fokusgruppeintervju som videokonferanse i forskning kan anbefales, selv om det kan være utfordrende og krever gode forberedelser. 
Det kvalitative forskningsintervjuet har mange ulike former, men uavhengig av form er formålet å forstå verden ut fra informantenes perspektiv, avdekke meningen i deres opplevelser og deres levde verden (1).

Forskningsintervjuet baserer seg på konversasjon mellom to eller flere mennesker om et tema av felles interesse, og hvor en intervjuer, en moderator, styrer samtalen og legger til rette for gode diskusjoner (2).

Fokusgrupper er en vel anvendt form for å gjennomføre kvalitative forskningsintervju og bygger på kommunikasjon mellom fire til åtte informanter (2).

\section{Hensikten med artikkelen}

Hensikten med denne artikkelen er å belyse våre erfaringer med fokusgruppeintervju som videokonferanse i et forskningsprosjekt. Fokusgruppeintervjuene er et delprosjekt av INFLUENCE, en klinisk studie (ClinicalTrials.gov NCTo3268876), som omhandler kvinner som er kirurgisk behandlet for eggstokkreft.

\section{«I dette prosjektet ønsket vi å få kvinnenes erfaringer og opplevelser.»}

I dette prosjektet ønsket vi å fă kvinnenes erfaringer og opplevelser. I tillegg ønsket vi også kvinnenes perspektiv, som brukere, om hva som er sentralt å få mer kunnskap om.

\section{Eggstokkreft er en alvorlig sykdom}

Eggstokkreft er en alvorlig kreftsykdom med høy dødelighet. I 2018 ble 444 kvinner i Norge diagnostisert med eggstokkreft, $344 \mathrm{~d} \varnothing \mathrm{de}$ av sykdommen samme år (3). Gjennomsnittsalderen ved diagnose er 65 år.

Kvinner diagnostisert med eggstokkreft får tilbud om behandling ved sykehus som har spesialisering og rutine på akkurat deres kreftform (3). 


\section{Deltakerne var fra ulike deler av landet}

Vårt forskningsprosjekt er tilknyttet Helse vest, og siden en av forfatterne har vært delaktig $i$

behandlingen av kvinner med eggstokkreft i Helse vest, ble informantene i fokusgruppen inkludert fra andre helseforetak.

Utfordringen var spørsmålet om hvordan vi skulle gjennomføre fokusgruppeintervjuer med kvinner fra ulike deler av landet, med vanskelig infrastruktur, lange avstander og høye kostnader knyttet til reise.

\section{«Vi var usikre på hvor mange kvinner som ville delta i fokusgruppen om det medførte reising.»}

Vi var også usikre på hvor mange kvinner som ville delta i fokusgruppen om det medførte reising.

\section{Å delta i en studie kan gi pasienten håp}

Å motta en kreftdiagnose for så å gjennomgå avansert kreftbehandling tar mye av kreftpasientenes tid, i tillegg kan bivirkninger av kreftbehandling oppleves krevende og utmattende.

Deltakelse i kliniske studier, både kvalitative og kvantitative, gir mange kreftpasienter et håp om å bli kurert eller et håp om å leve lenger, men selv med håp om å bli frisk eksisterer det barrierer for deltakelse i kliniske studier (4).

\section{Ville flere delta om de slapp å reise?}

Norge er også et land med utfordrende topografi og lange avstander mellom hjem og sykehus. Hvordan stiller alvorlig syke pasienter seg til å delta i et forskningsprosjekt som ikke har en helsegevinst for dem selv, men som kan fremme ny kunnskap som kan komme andre til gode?

Det er ikke noe klart svar, noen vil likevel velge å delta, men kunne vi nå ut til flere ved å tilby pasientene å delta i forskningsprosjektet fra sin egen stue? 


\section{Hva er en videokonferanse?}

Det finnes flere definisjoner på hva videokonferanse er, felles for dem er at det er en «live» og synlig forbindelse mellom to eller flere mennesker som sitter på ulike steder, og hvor formålet er kommunikasjon.

Videokonferanser kan deles i såkalte «enkle» videokonferanser, hvor bilde og tekst utveksles, og mer sofistikerte videokonferanser som gir full-motion videobilder og lyd av høy kvalitet (5). I dagens samfunn er bruken av videokonferanse stor innenfor de fleste områder av næringslivet, akademia og $\mathrm{i}$ helsevesenet, og kanskje enda mer nå etter covid-19.

De mest kjente plattformene, i tilfeldig rekkefølge, kjenner mange til som Microsoft Teams, Skype, Zoom og Google Meet, men også såkalte sosiale medier som FaceTime, Snapchat og Messenger åpner for muligheten for videokonferanser.

\section{Skype blir brukt i helsevesenet}

Skype har i mange år blitt brukt som kommunikasjonsplattform innenfor helsevesenet, som video for å få ekspertuttalelser, video i kombinasjon med andre helserelaterte tiltak, video mellom parter i helsevesenet, hjemmet og pårørende og video for mer effektiv administrasjon (6).

Det er også gjort studier på Skype innenfor epidemiologisk forskning med varierende erfaringer og resultat. En tysk studie fra 2012 konkluderte med at Skype ikke var et gjennomførbart verkt $\varnothing \mathrm{y}$ for datasamling i Tyskland (7). Heldigvis har den teknologiske utviklingen gått fremover siden 2012.

Oates sin studie fra 2015 konkluderer med at sensitivitet og samarbeid kan oppnås ved bruk av Skype, og at å bruke Skype åpner opp for geografisk spredning, er billig og raskere enn møter ansikt til ansikt (8). 


\section{Videokonferanser blir stadig mer vanlig}

Innenfor akademisk forskning blir Internett og onlinemedier stadig oftere brukt til å samle inn primærdata. $\AA$ gjennomføre fokusgruppeintervjuer som videokonferanse er et eksempel på det, selv om andre måter som bruk av spørreskjema var tidligere ute.

Det har blitt fremmet kritiske spørsmål om i hvilken grad fokusgruppeintervju, som videokonferanse i forskning, er egnet når essensen i metoden ligger $i$ at informanter samtaler om et definert tema, ledet av moderator og sitter samlet i samme rom (9).

\section{De første studiene av nettbaserte fokusgrupper}

Den første asynkrone dokumenterte nettbaserte fokusgruppen er datert tilbake i 1997, av Peter Murray og hans studie av geografisk spredt helsepersonell, og bruk av e-post (10). Karakteristikken av hans populasjon, at de var geografisk spredt, medførte at online-grupper på seks til åtte informanter var passende (10).

Senere har det blitt utført synkrone online fokusgruppeintervjuer som den Stewart først gjennomførte i 1998 (11). Erfaringer fra synkrone online fokusgrupper er at de kan skape et sett av mer komplekse interaksjoner grunnet forsinkelser av tid, hvilket kan medføre at informantenes stemmer overlapper hverandre, som igjen kan resultere i utfordringer ved transkribering til manus (9).

En annen utfordring som ble observert var at slike komplekse interaksjoner med overlappinger kan gjøre oppgaven til moderator mer kompleks og utfordrende (9).

\section{Slik gikk vi frem - trinn for trinn}

Helsefaglig forskning blir definert som «en virksomhet som utføres med vitenskapelig metodikk for å skaffe til veie ny kunnskap om helse og sykdom» (12). 
Vårt forskningsprosjekt er helsefaglig forskning, hvor vi innhentet helseopplysninger fra pasienter med eggstokkreft. Det krevde godkjenning av Regional Etisk Komite (REK) og av Personvernombudet (PO) i helseforetaket (13).

\section{Metoden ble godkjent av IKT-avdelingen}

Helseopplysningene var av sensitiv art, som innebar et løfte om konfidensialitet, fortrolighet og tillit (14). Siden vi skulle utføre fokusgruppeintervjuene som videokonferanse, måtte vi også ha godkjenning av den ansvarlige for IKT-sikkerheten i helseforetaket.

Anonymisering av informanter og data er utfordrende uavhengig av om intervjuet er fysisk eller nettbasert $(14,15)$. Imidlertid, når man bruker nettbasert videokonferanse, er det i tillegg en mulighet for at informantene lett kan spores digitalt og at sensitiv informasjon om deltakerne blir etterlatt til bruk av andre som ikke skal ha tilgang (14).

\section{Deltakerne fikk informasjon}

Informantene i vår fokusgruppe ble rekruttert gjennom pasientorganisasjonen Gynkreftforeningen.

Kvinnene mottok muntlig informasjon om forskningsprosjektet sammen med informasjonsbrev og samtykkeskjema, hvor det ble opplyst om at intervjuene ville bli gjennomført som videokonferanse. Under den muntlige informasjonen ble det opplyst om at deltakelse i forskningsprosjektet krevde god nettilgang og egen datamaskin.

\section{Kvinnene fikk tilsendt en intervjuguide}

Etter at samtykkeskjemaet var signert, fikk kvinnene tilsendt intervjuguide med innledende spørsmål, brukermanual til Skype og en sikkerhetsrutine til videokonferansene. Selv om mange i dag har Skype, er det ikke alle som har Skype for business, som er nødvendig når flere skal delta med lyd og bilde samtidig. 
Etter anbefaling fra den ansvarlige for IKTsikkerheten, utarbeidet forfatterne en brukermanual til Skype for business som vi kalte «Informasjon til pasient videokonsultasjon», til bruk i vårt forskningsprosjekt. Brukermanualen inneholdt informasjon, i form av bilde og tekst, om hvordan kvinnene kunne kople seg opp uten å ha installert Skype for business.

\section{Vi utarbeidet en sikkerhetsrutine}

Vi utarbeidet også en sikkerhetsrutine for gjennomføring av fokusgruppeintervjuene.

Forholdsregler som vi måtte ta hensyn til ved utarbeidelse av sikkerhetsrutinene var blant annet hvordan intervjuene skulle gjennomføres, informasjon om hvor moderatorene og informantene skulle sitte med tanke på hvem som kunne se eller lytte til samtalen, samt informasjon om hvordan opptak og lagring av intervjuene skulle gjennomføres og hvem som skulle ha tilgang til opptakene.

\section{«De kunne ringe inn om de hadde problemer med å kople seg opp.»}

Før første fokusgruppeintervju, hadde moderator en testoppkopling med hver av kvinnene. De hadde også fătt telefonnummeret til moderator og kunne ringe inn om de hadde problemer med å kople seg opp.

\section{Det var fem kvinner i gruppen}

Fokusgruppeintervjuene ble utført av forfatterne som moderator og med-moderator, og det var fem kvinner i gruppen. Intervjuene ble tatt opp med stemmeopptaker, og med-moderator noterte underveis $\mathrm{i}$ intervjuet. 
Vi var usikre på utfordringene vi eventuelt kunne møte ved å ha for mange informanter med, når samhandlingen og dynamikken mellom informantene er selve essensen i metoden (16). Det var også usikkerhet knyttet til mulige tekniske utfordringer, vi hadde derfor tilgang til IT-hjelp under selve intervjuene.

\section{Våre erfaringer med videokonferanse}

Både moderator og med-moderator hadde god erfaring med å bruke Skype, men ikke innenfor forskning. Vi hadde ikke inngående kunnskap om hvordan vi skulle løse eventuelle tekniske utfordringer, som blant annet utfordringer med nettoppkopling og forsinkelse på lyd under intervjuene og at vi ikke kunne nå alle informantene.

Vi erfarte at det til tider var vanskelig for kvinnene å inntre i videosamtalen, men med litt tålmodighet fra alle parter gikk det fint.

Fokusgruppe som forskningsintervju innebærer at moderator legger til rette for gode gruppediskusjoner, og vi var spent på om våre samtaleferdigheter som moderatorer ville bli påvirket av at forskningsintervjuet ble gjennomført som videokonferanse $(1,2)$.

Formålet med fokusgruppeintervju er at informantene selv skal styre samtalen og utforske egen kunnskap og opplevelser, ikke bare i form av hva de tenker, men hvordan de tenker og hvorfor (16).

\section{Samtalen fløt lett mellom kvinnene}

Fokusgruppeintervjuer er basert på tillit, som moderatorer la vi til rette for at kvinnene skulle bli trygge på hverandre slik at de ønsket å dele.

Vår opplevelse er at samtalen fløt lett mellom kvinnene, og at vi kunne be dem om å utdype interessante temaer som belyste spørsmål, uten at noe ble holdt tilbake. Jo tryggere kvinnene var på hverandre og på oss, jo mer ønsket de å dele (2). 


\section{«Jo tryggere kvinnene var på hverandre og på oss, jo mer ønsket de å dele.»}

Murrays erfaringer ble tatt med i vår måte å stille spørsmål på, ved at vi stilte få direkte spørsmål, da dette kunne føre til en serie direkte svar fra kvinnene fremfor å stimulere diskusjonen (10). Moderator styrte diskusjonen og kom med oppfølgingsspørsmål.

Vi var forberedt på at sensitive temaer kunne komme opp i gruppesamtalene, som måtte behandles med omhu. Vi måtte også ha et blikk for forskjeller i makt både mellom moderatorer og informanter, men også informantene seg imellom (2).

\section{Vi var usikre på rammen for intervjuet}

Rammen rundt en fokusgruppe skal være avslappet, gjerne med forfriskninger og sittende i en sirkel for å fremme atmosfæren og gi rom for trygghet $(16,17)$. Når da fokusgruppen møtes i en videokonferanse, sittende hver for seg hjemme, ville informantene styre samtalen og dele tankene sine på samme måte som om de satt sammen i en sirkel i samme rom?

Som forfattere og moderatorer var vi usikre på om atmosfæren, dynamikken og samhandlingen mellom kvinnene ville bli påvirket av at fokusgruppeintervjuet ble gjennomført som en videokonferanse.

Vi erfarte at kvinnene ga rom til hverandre, lyttet og ventet, de viste empati overfor hverandre og delte egne erfaringer og opplevelser på en måte som gjorde inntrykk.

\section{Kvinnene følte seg trygge}

Tilbakemeldingene fra kvinnene har vært overveiende positive. De erfarte rammen som trygg, som ifølge Kitzinger fremmer mer åpne diskusjoner (16).

Kvinnene kunne sitte hjemme i sin egen stue og gjennomføre intervjuene, det tok mindre av deres tid og gjorde at det var lettere for dem å delta. 


\section{Konklusjon}

Vår erfaring er at fokusgruppeintervju som videokonferanse i forskning kan anbefales, selv om det kan være utfordrende og krever gode forberedelser.

Vi erfarte stor grad av brukertilfredshet, og at fokusgruppeintervju som videokonferanse kan være like bra til å gjennomføre et kvalitativt forskningsintervju som å være fysisk til stede.

Videokonferanse er kostnadseffektivt, det er ingen reiseutgifter, informantene trenger heller ikke ekstra teknisk utstyr utover en datamaskin og nettilgang, men det krever at informantene og arrangørene er oppmerksomme på tekniske utfordringer som kan oppstå.

I dag, med utfordringer som covid-19, er det høyst relevant og gjennomførbart å bruke videokonferanser innenfor helseforskning.

\section{Referanser}

1. Brinkmann S, Kvale S. Interviews: Learning the craft of qualitative research interviewing. Thousand Oaks: Sage; 2015.

2. Malterud K. Fokusgrupper som forskningsmetode for medisin og helsefag. Oslo: Universitetsforlaget; 2012.

3. Kreftregistret. Cancer in Norway 2018 - Cancer incidence, mortality, survival and prevalence in Norway. Oslo: Kreftregisteret; 2019.

4. Mills EJ, Seely D, Rachlis B, Griffith L, Wu P, Wilson $\mathrm{K}$, et al. Barriers to participation in clinical trials of cancer: a meta-analysis and systematic review of patient-reported factors. The Lancet Oncology. 2006;7(2):141-8. 
5. SearchUnifiedCommunications. Video

conferencing (video conference). 2016. Tilgjengelig fra: https://searchunifiedcommunications.techtarget.com/d efinition/video-conference (nedlastet 28.05.2020).

6. Ekeland AG, Hansen AH, Bergmo TS. Clinical videoconferencing as eHealth: a critical-realist review and qualitative meta-synthesis. J Med Internet Res. 2018;20(10):e282.

7. Weinmann T, Thomas S, Brilmayer S, Heinrich S, Radon K. Testing Skype as an interview method in epidemiologic research: response and feasibility. Int J Public Health. 2012;57(6):959-61.

8. Oates J. Use of Skype in interviews: The impact of the medium in a study of mental health nurses. Nurse researcher. 2015;22(4).

9. Stewart K, Williams M. Researching online populations: the use of online focus groups for social research. Qualitative Research. 2005;5(4):395-416.

10. Murray PJ. Using virtual focus groups in qualitative research. Qualitative health research. 1997;7(4):542-9.

11. Stewart F, Eckermann E, Zhou K. Using the internet in qualitative public heath research: A comparison of chinese and australian young women's perceptions of tobacco use. Internet Journal of health promotion. 1998;12.

12. NOU 2005: 1. God forskning - bedre helse. Lov om medisinsk og helsefaglig forskning, som involverer mennesker, humant biologisk materiale og helseopplysninger (helseforskningsloven). Oslo:

Departementenes servicesenter, Informasjonsforvaltning; 2005. 
13. Salbu AK. Regionale komiteer for medisinsk og helsefaglig forskningsetikk (REK). Oslo; De nasjonale forskningsetiske komiteene: 2014. Tilgjengelig fra: https://www.etikkom.no/FBIB/Praktisk/Forskningsetisk e-enheter/Regionale-komiteer-for-medisinsk-oghelsefaglig-forskningsetikk/ (nedlastet 24.05.2020).

14. De nasjonale forskningsetiske komiteene.

Forskningsetisk veileder for internettforskning. Oslo;

De nasjonale forskningsetiske komiteene: 2019 . Tilgjengelig fra:

https://www.etikkom.no/forskningsetiskeretningslinjer/veileder-for-internettforskning/ (nedlastet 24.05.2020).

15. Saunders B, Kitzinger J, Kitzinger C. Anonymising interview data: challenges and compromise in practice. Qual Res. 2015;15(5):616-32.

16. Kitzinger J. Qualitative research: introducing focus groups. BMJ. 1995;311:299. Tilgjengelig fra: https://www.bmj.com/content/311/7000/299. (nedlastet 20.05.2020).

17. Krueger RA, Casey MA. Designing and conducting focus group interviews. Minnesota, USA; 2002. 